Cultural distance, political risk and location decisions of emerging-market multinationals: A comparison between Chinese and Indian firms

Diego Quer (corresponding author)

Associate Professor

Department of Management, University of Alicante, Spain

P.O. Box 99, E-03080 Alicante, Spain

e-mail: diego.quer@ua.es

\title{
Enrique Claver
}

Professor

Department of Management, University of Alicante, Spain

P.O. Box 99, E-03080 Alicante, Spain

e-mail: enrique.claver@ua.es

\author{
Laura Rienda \\ Associate Professor \\ Department of Management, University of Alicante, Spain \\ P.O. Box 99, E-03080 Alicante, Spain \\ e-mail: laura.rienda@ua.es
}




\section{ABSTRACT}

The international expansion of emerging-market multinational enterprises (MNEs) is becoming a research topic of increasing interest among international business scholars. One of the specific research questions arising is whether conventional theoretical arguments originated in studies on developed-country MNEs are still valid for explaining the international behavior of emerging-market MNEs. Drawing on the institutional theory, this paper argues that the influence of host country institutional factors on location decisions differs between Chinese and Indian MNEs. We hypothesize that the negative impact of both cultural distance and political risk on location decisions is lower for Chinese MNEs as compared to Indian MNEs. From a sample of 832 outward foreign direct investments (OFDIs) we obtain empirical support for these hypotheses.

KEYWORDS: emerging-markets; multinationals; location decisions.

JEL CLASSIFICATION: F21, F23, M16.

\section{Introduction}

The international expansion of multinational enterprises (MNEs) from emerging markets is a rapidly evolving phenomenon which is reshaping the global landscape (Jormanainen and Koveshnikov, 2012). The unique attributes of these emerging-market MNEs make necessary to re-evaluate the underlying assumptions of conventional theories mainly stemming from developed-country MNEs (Kim and Aguilera, 2016).

Over the last years, China and India are the most prominent within this trend of outward foreign direct investment (OFDI) from emerging economies, with some Chinese and Indian MNEs carrying out significant cross-border mergers and acquisitions (M\&As) and becoming global players (De Beule and Duanmu, 2012). 
Existing research comparing the international behavior of Chinese and Indian MNEs is still scant. Previous papers have analyzed several issues: their strategies to fit the changing environment and participate in global markets (Kothari, Kotabe and Murphy, 2013), their comparative ownership advantages (Sun et al., 2012), the motives and performance of their cross-border M\&As (Nicholson and Salaber, 2013), the influence of their home countryspecific macroeconomic factors (Tolentino, 2010), the characteristics, impacts and policy implications of their investments (Milelli, Hay and Shi, 2010) or the locational determinants of their OFDI (Brienen, Burger and van Oort, 2010; De Beule and Duanmu, 2012; De Beule and Van Den Bulcke, 2012; Duanmu and Guney, 2009; Pradhan, 2011).

Foreign location choice is a research topic that has received much attention from both scholars and managers as this decision may affect firm's profitability (Jain, Kothari and Kumar, 2016). Notwithstanding this, past research dealing with location choice of Chinese and Indian MNEs did not specifically address the influence of two traditional host country institutional factors that affect location decisions of MNEs, namely, cultural distance and political risk. In order to fill this gap, this paper aims to add to this body of literature by analyzing the impact of the above mentioned host country institutional factors on the location choice of Chinese and Indian MNEs. Thus, we try to investigate whether these emergingmarket MNEs behave in a conventional way similar to that shown by developed-country MNEs. Furthermore, we analyze if there are differences between Chinese and Indian MNEs when facing a high level of political risk and cultural distance in host countries.

We seek to make several contributions. First, we extend institutional theory by analyzing if emerging market-MNEs challenge some of the assumptions originally arising from MNEs from developed economies. In doing so, we also contribute to the epistemological debate generated among international business scholars about the validity of extant theories in the case of emerging-market MNEs (Buckley et al., 2016a; Cuervo-Cazurra, 
2012; Mathews, 2006; Rugman, 2010). As Xu and Meyer (2013) suggest, research in emerging economies leads the charge in advancing theories by drawing attention to the context-specific nature of strategic management.

Second, we also contribute to the literature on Chinese and Indian MNEs from a comparative point of view. Although there is extensive empirical research on emerging market MNEs, in particular on Chinese MNEs, empirical papers that comparatively analyze the international behavior of Chinese and Indian MNEs are still limited. More precisely, although some papers that have compared the locational determinants of both MNEs dealt with political risk, none of them have addressed the role of cultural distance.

In subsequent sections, we present theoretical explanations and develop hypotheses on the different impact of cultural distance and political risk on Chinese and Indian OFDI location. We then present our research methodology and results. We end the paper with a discussion of the findings together with the main contributions and limitations of our study, as well as proposing directions for future research.

\section{Theory and hypotheses development}

Institutional theory focuses on the role of political, social, and economic systems surrounding firms in shaping their behavior. These 'rules of the game' are both formal -laws and regulations-and informal-customs and traditions (North, 1990). There is an increasing recognition among researchers that these formal and informal institutions significantly shape the strategy of firms in emerging economies (Hoskisson et al., 2000; Peng, Wang and Jiang, 2008). More precisely, Wright et al. (2005) emphasized that institutional theory is a good way to lay a foundation for the internationalization of emerging-economy firms entering both developing and developed economies. A recent literature review shows that institutional 
theory is the most popular theoretical perspective among research papers on emergingeconomy strategies (Xu and Meyer, 2013).

\subsection{Cultural distance and location choice}

From an institutional perspective, culture may be considered as a part of the environment's informal institutions, which underpin formal institutions (Peng, Wang and Jiang, 2008). The conventional argument is that cultural distance between countries creates obstacles for doing business abroad, thus affecting location decisions of MNEs. Cultural differences may lead to misinterpretation and miscommunication (Blomkvist and Drogendijk, 2013), increasing postacquisition costs (Malhotra, Zhu and Locander, 2010) and making it difficult to build social legitimacy in the host country (Cui and Jiang, 2010). For these reasons, MNEs would prefer to enter a cultural setting similar to that of their home country (Kang and Jiang, 2012). Empirical evidence provides support for this negative relationship between cultural distance and OFDI location choice (Bhardwaj, Dietz and Beamish, 2007).

Several scholars argue that cultural distance affect Indian OFDI location in a conventional way. As Pradhan (2008a, 2008b) reports, Indian OFDI has evolved over time in two phases, in tune with the developments of Indian economy and policy reforms. During the first phase (up to 1990), forces of proximity in geography, language, history or ethnicity had a strong impact on the locational decisions of Indian MNEs, with developing countries of South-East and East Asia emerging as top destinations. Although developing countries continued to be important destinations, during the second phase (from 1991 onwards) location of Indian OFDI moved away from developing to developed countries, with two countries which share a common language with India being the largest recipients: the UK and the US.

In the case of Chinese MNEs, there are arguments suggesting a lower influence of cultural distance on location decisions. Prior inward internationalization is one of the 
distinctive characteristics of Chinese OFDI. China has been one of the largest global recipients of FDI inflows since 1978. Thus, strategic partnerships between Chinese firms and foreign MNEs in China have provided the Chinese side with valuable resources and capabilities at home, in particular managerial know-how and international experience, that are useful for subsequent outward internationalization (Luo et al., 2011; Luo and Wang, 2012; Ning and Sutherland, 2012; Xia et al., 2014). As a consequence, the potential negative impact of cultural distance on Chinese OFDI may have been attenuated, in part, by this process of inward FDI (Luo and Tung, 2007).

Moreover, in recent years strategic asset-seeking is becoming increasingly important as a driving factor for Chinese OFDI (Buckley et al., 2007, 2016b; Huang and Renyong, 2014; Rui and Yip, 2008; Yang et al., 2014). Hence, many Chinese firms, rather than exploiting an existing competitive advantage, are seeking to acquire strategic assets abroad such as technology, managerial know-how or internationally recognized brands. The usual destinations for acquiring these strategic assets are developed countries (mainly the US and Europe) with a greater cultural distance from China.

Prior research comparing locational determinants of Chinese and Indian OFDI did not focus on cultural issues. However, the influence of cultural distance has been addressed by studies that separately analyzed location decisions of Chinese and Indian MNEs. Past research supports the conventional viewpoint, namely, that cultural proximity is an important factor for locational distribution of Indian OFDI (Anwar and Mughal, 2013; Brienen, Burger and van Oort, 2010; Nunnenkamp et al., 2012; Pradhan and Singh, 2011). However, empirical evidence is not conclusive in the case of Chinese firms. Although several scholars found that Chinese OFDI was negatively associated with the cultural distance between China and the host country (Blomkvist and Drogendijk, 2013; Buckley et al., 2007, 2016b; Malhotra, Zhu and Locander, 2010), others did not support this conventional finding. Kang and Jiang (2012) 
only obtained marginal support for the negative relationship between cultural distance and Chinese OFDI. Li, Li and Shapiro (2012), Quer, Claver and Rienda (2012) and Ramasamy, Yeung and Laforet (2012) reported mixed results, since they obtained the expected result only using a specific measure of cultural distance or focusing on Chinese state-owned enterprises (SOEs).

In keeping with the above arguments, we posit that the conventional negative influence of cultural distance applies in Indian MNEs' location decisions, but not in the case of Chinese MNEs. Therefore, we propose the following:

Hypothesis 1. The negative impact of cultural distance on location decisions is lower for Chinese MNEs as compared to Indian MNEs.

\subsection{Political risk and location choice}

Political risk is one of the most researched host country institutional factors. The conventional wisdom suggests that a high political risk in a host country is negatively associated with OFDI location, since MNEs will prefer to enter countries where regulative institutional constraints are less repressive (Kang and Jiang, 2012). A higher degree of uncertainty or an increased asset exposure in the case of an eventual expropriation may hinder OFDI decisions (Brouthers, 2002; Pak and Park, 2004).

The rise of emerging-market MNEs is challenging this conventional argument. They suffer the competitive disadvantage of operating in a home country with an underdeveloped institutional environment. However, this disadvantage can turn into an advantage over developed-country MNEs when doing business in host countries with similarly weak institutional environments (Cuervo-Cazurra and Genc, 2008).

However, we argue that this effect is more evident in the case of Chinese MNEs due to the idiosyncratic characteristics of the institutional environment in China as compared to that 
of India. There are several institutional differences between China and India. One of them deals with the differences between their paradigms of economic growth (Das, 2010) The Chinese government has played an executive role, actively participating in the market process of resource allocation. Conversely, the Indian model of economic growth has been driven by the private sector with the Indian government playing a more indirect role.

As a consequence, while the vast majority of China's largest companies are SOEs receiving support from the Chinese government, most of India's businesses are private firms and they have to generate their own income to survive (Devonshire-Ellis, 2010). This may lead to a managerial decision-making more dependent on political considerations in Chinese companies as compared to their Indian counterparts.

Unlike the case of Chinese OFDI, which has been mainly driven by SOEs, private firms have been the leading players of Indian OFDI, especially during the early stages of development (Pradhan, 2011). Chinese SOEs, thanks to the governmental support, may be less influenced by host country political risk compared to private firms (Duanmu, 2012, 2014; Ramasamy, Yeung and Laforet, 2012). Since they are subject to Chinese government institutional influences, they may not be only profit-maximizers (Buckley et al., 2007). Furthermore, bilateral diplomatic relations between China and the host country may serve as a risk-reduction device, in particular for Chinese SOEs (Buckley et al., 2016b; Duanmu, 2014; Zhang, Jiang and Zhou, 2014).

Thus, although Li, Li and Shapiro (2012) and Lu et al. (2014) show that welldeveloped institutions in the host country increase the likelihood of Chinese OFDI, other papers report that Chinese MNEs find it easier to deal with corrupt conditions in host countries (Malhotra, Zhu and Locander, 2010), that risky political environments do not deter Chinese OFDI (Duanmu, 2012, 2014; Quer, Claver and Rienda, 2012) or even that Chinese 
OFDI is attracted by political risk (Buckley et al., 2007, 2016b; Han, Chu and Li, 2014; Kang and Jiang, 2012; Kolstad and Wiig, 2012; Ramasamy, Yeung and Laforet, 2012).

Prior studies comparing Chinese and Indian OFDI location have investigated the role of several host country political issues. Although their results are not conclusive (Duanmu and Guney, 2009; Pradhan, 2011), we find evidence in line with our arguments, suggesting that political risk deters Indian MNEs more than Chinese MNEs. De Beule and Van Den Bulcke (2012) find that Chinese MNEs are rather indifferent toward corrupt host countries, whereas Indian MNEs are more put off by corruption. Similarly, De Beule and Duanmu (2012) report that rule of law, control of corruption and regulatory quality in the host country play a conventional role in attracting Indian OFDI but they are not significant in the case of Chinese OFDI. Although not comparing with Chinese OFDI, Anwar and Mughal (2012) and Nunnenkamp et al. (2012) also report a conventional behavior of Indian MNEs, since they find that better governance and institutions in the host country attract more OFDI from India.

These arguments lead us to suggest that political risk does not affect Chinese MNEs' location in a conventional way. We therefore hypothesize the following:

Hypothesis 2. The negative impact of political risk on location decisions is lower for Chinese MNEs as compared to Indian MNEs.

\section{Data and method}

\subsection{Sample}

The sample for this study consisted of 832 OFDIs in 112 countries between 2005 and 2014: 599 carried out by Chinese MNEs and 233 carried out by Indian MNEs. We collected data from several secondary data sources: China Global Investment Tracker (The Heritage Foundation), China Daily, Global Times, The Economic Times, The Hindu Business Line, Centre for Monitoring Indian Economy, Business Standard and Forbes Global 2000. We also 
checked the corporate websites of Chinese and Indian investing companies identified in the above-mentioned information sources.

\subsection{Dependent variable}

Number of OFDIs. In our study, the dependent variable is the total number of OFDIs made by Chinese and Indian firms in each host country. This is a count variable that has been previously used in prior research on location decisions of MNEs (Brienen, Burger and van Oort, 2010; Deng and Yang, 2015; Malhotra, Zhu and Locander, 2010; Pradhan and Singh, 2011; Ramasamy, Yeung and Laforet, 2012).

\subsection{Independent variables}

Cultural distance. This variable was operationalized by the Kogut and Singh (1988) index, using the extended Hofstede's model with six dimensions (Hofstede, Hofstede and Minkov, 2010). A high score on this measurement means a greater cultural distance between China and/or India and each host country. This index has been extensively used in the international business literature. In the case of emerging-market MNEs, it has been used by Blomkvist and Drogendijk (2013), Kang and Jiang (2012), Li, Li and Shapiro (2012), Malhotra, Zhu and Locander (2010) and Quer, Claver and Rienda (2012), among others.

Political risk. This variable was measured using the political risk rating of the International Country Risk Guide (Political Risk Services Group). This measure has been used in prior studies on Chinese and/or Indian OFDI (Buckley et al., 2007, 2016b; Duanmu, 2012; Duanmu and Guney, 2009; Han, Chu and Li, 2014; Quer, Claver and Rienda, 2012; Rienda, Claver and Quer, 2013). Since higher values of this index indicate a lower political risk, we transformed this variable in order to facilitate the interpretation of the results. Thus, higher values indicate higher risk. 


\subsection{Control variables}

We controlled for a number of factors that have been shown to affect location decisions of Chinese and Indian MNEs in prior research. More precisely, we controlled for the motivation of the OFDI decision, namely, looking for markets, natural resources or strategic assets in the host country. We also included geographic distance, administrative distance and the role of diasporas as control variables.

Host market size. This variable is related to a market-seeking motivation. We employed the GDP of each host country as a measure (log transformation), using data from the World Bank (Anwar and Mughal, 2012; Buckley et al., 2007, 2016b; De Beule and Duanmu, 2012; De Beule and Van Den Bulcke, 2012; Duanmu and Guney, 2009; Malhotra, Zhu and Locander, 2010; Nunnenkamp et al., 2012).

Host market growth. This variable has been also included to capture the effect of a market-seeking motive. It was measured by the GDP growth of each host country (annual \%), using data from the World Bank (Anwar and Mughal, 2012; Buckley et al., 2007, 2016b; Duanmu and Guney, 2009; Kang and Jiang, 2012; Nunnenkamp et al., 2012; Ramasamy, Yeung and Laforet, 2012).

Natural resource endowment. The natural resource endowment of the host country was used as a proxy of a resource-seeking motivation. The measurement was the percentage of ore and metal exports to total merchandize exports by country, using data from the World Development Indicators of the World Bank (Anwar and Mughal, 2012; Buckley et al., 2007, 2016b; De Beule and Duanmu, 2012; De Beule and Van Den Bulcke, 2012; Duanmu and Guney, 2009).

Patent registrations. The total number of patent registration (both resident and nonresident) in a host country was used as a proxy of a strategic-asset seeking motive (Buckley et 
al., 2007, 2016b; De Beule and Duanmu, 2012; De Beule and Van Den Bulcke, 2012). We also used data from the World Development Indicators of the World Bank (log transformation).

Geographic distance. We also controlled for the effect of geographical distance. This variable was measured by the distance in kilometers between the capital cities of each host country and Beijing (China) and New Delhi (India), respectively (Anwar, Hasse and Rabbi, 2008; Anwar and Mughal, 2012, 2013; Buckley et al., 2007, 2016b; Duanmu and Guney, 2009; Malhotra, Zhu and Locander, 2010). We also used a log transformation of this variable.

Administrative distance. Administrative distance refers to the historical and political associations shared by countries that greatly affect trade between them (Ghemawat, 2001). Absence of colonial ties, absence of political association, political hostility and lack of preferential trading arrangements are attributes that create administrative distance between countries. Differences in languages or legal systems between markets tend to increase both the costs and the risks of a transaction (Dow and Karunaratna, 2006). For instance, colonial ties are a potential antecedent to differences in languages and political systems. Moreover, existing political relations and investment and trade ties between the home and the host countries need to be accounted for. Therefore, in order to control for these factors, we included two additional variables. In the case of Indian OFDI, we controlled for issues such as common language, similar legal system or past colonial ties by considering if the host country is a member of the Commonwealth of Nations. This intergovernmental organization plays a crucial role in policy, political, social and developmental aspects for member countries, one of them being India. Thus, we used a dummy variable that takes the value 1 if the host country is a member of the Commonwealth of Nations, and 0 otherwise (Buckley, Forsans and Munjal, 2012). In the case of Chinese OFDI, we controlled for the above-mentioned factors by considering if the host country participates in the Belt and Road Initiative, also called One 
Belt, One Road (OBOR). This initiative was officially launched by the Chinese government in September 2013 and it is considered as a key national concept and foreign policy priority for China. The Belt and Road initiative aims at contributing to greater economic integration within Asia, between Asia and Europe, and between Asia and Africa through a diversity of activities and projects (Van der Putten et al., 2016). Together, the countries along the Belt and Road will create an economic cooperation area (Chin and He, 2016). China's long-term goals for the Belt and Road go beyond economic and commercial integration and encompass policy coordination and people-to-people bonds, including technological and educational exchange between countries. Thus, in order to control for the effect of the Belt and Road initiative on the location decisions of Chinese firms, we included a dummy variable that takes the value 1 if the host country participates in the Belt and Road initiative, and 0 otherwise (China International Trade Institute, 2015).

Diaspora. Apart from the administrative distance, the size of the diaspora living in the host country may also affect location decisions of MNEs (Nunnenkamp et al., 2012). Diasporas play a crucial role in augmenting trade, OFDI and prosperity of a country. They facilitate acquisition and exchange of technical know-how and market information, thus being considered as social capital (Anwar and Mughal, 2013). One of the underlying factors is a common language that facilitates communication and reduces transaction costs. English is widely spoken in India and, as stated above, Indian people share cultural ties with the UK and other former British colonies. As a consequence, several studies report that a large community of overseas Indian in other English speaking countries is positively associated with Indian investments in those host countries (Anwar and Mughal, 2013; Brienen, Burger and van Oort, 2010; Nunnenkamp et al., 2012; Pradhan and Singh, 2011). Although with less conclusive results, past research on Chinese OFDI also support this influence of diasporas (Buckley et al., 2007; Li, Li and Shapiro, 2012; Quer, Claver and Rienda, 2012; Ramasamy, Yeung and 
Laforet, 2012). Therefore, we controlled for the Chinese and Indian diaspora' role in attracting OFDI from China and India to their respective host countries. We created a dummy variable that takes value 1 when the percentage of ethnic Chinese or Indian in the host population is higher than one percent, and 0 otherwise (Brienen, Burger and van Oort, 2010; Buckley et al., 2007; Quer, Claver and Rienda, 2012). In the case of Chinese diaspora, we used data from the Shao Center of the Ohio University, whereas the Non Resident Indians and Persons of Indian Origin Division - Ministry of External Affairs of India was used as a data source for Indian diaspora.

\section{Results and discussion}

Table 1 presents descriptive statistics and correlations. Before conducting the regression analysis, we ran a variance inflation factor (VIF) test. VIF values are all below 10. Thus, no serious collinearity problems are found (Kutner, Nachtsheim and Neter, 2004).

\section{Insert Table 1 about here}

Our dependent variable is the number of OFDIs in each host country. This is a count variable ranging from cero to a certain positive number. Thus, it is inappropriate to use standard multiple regression models as ordinary least squares (OLS) regressions (Long, 1997). In order to correct for over-dispersion, that is when the conditional variance exceeds the conditional mean, we use a negative binomial regression model (Greene, 2003). This model has been employed in prior research on emerging-market MNEs considering a similar count dependent variable (Brienen, Burger and van Oort, 2010; Buckley et al., 2016a; Deng and Yang, 2015).

Table 2 shows the estimates of the negative binomial regression used for testing the hypotheses. We split the sample into two subsamples. Models 1 and 2 report the results for the subsample of Chinese OFDI. Model 1 includes control variables only, while Model 2 adds 
all independent variables. Similarly, Models 3 and 4 focus on the subsample of Indian OFDI, Model 3 considering only control variables and Model 4 including all variables ${ }^{1}$.

\section{Insert Table 2 about here}

Hypothesis 1 states that the conventional negative impact of cultural distance on location decisions is lower for Chinese MNEs as compared to Indian MNEs. As Table 2 reports, the coefficient of cultural distance is negative and highly significant for Indian OFDI in Model 4 ( $\mathrm{p}<0.001)$, whereas it is not significant for Chinese OFDI (Model 2). Thus, the greater the cultural distance between India and the host country, the lower the number of Indian OFDIs in that host country. On the contrary, cultural distance does not affect the number of Chinese OFDIs in a given host country. Therefore, Hypothesis 1 is supported.

As we pointed out before, although prior studies that have compared location determinants of Chinese and Indian MNEs did not address the effect of cultural distance, this effect was considered by studies analyzing separate samples of Chinese and Indian MNEs. Our result is consistent with that of several studies who reported a negative influence of cultural distance on locations decisions of Indian MNEs (Anwar and Mughal, 2013; Brienen, Burger and van Oort, 2010; Nunnenkamp et al., 2012; Pradhan and Singh, 2011). Likewise, the non-significant result reported here for Chinese MNEs is in line with the lack of conclusive support obtained in some prior research (Kang and Jiang, 2012; Li, Li and Shapiro, 2012; Quer, Claver and Rienda, 2012; Ramasamy, Yeung and Laforet, 2012).

To conclude, our empirical results reinforce the view that Chinese MNEs show a nonconventional behavior when facing cultural differences as compared to their Indian counterparts. As stated above, some distinctive characteristics of the internationalization process of Chinese firms help to explain this result. First, the role played by prior inward internationalization may provide Chinese firms with useful cross-cultural management skills for their subsequent outward internationalization. Second, strategic-asset seeking is an 
important driver of Chinese MNEs, and the strategic assets they need are usually available in developed countries that are culturally distant from China.

Hypothesis 2 posits that the conventional negative impact of political risk on location decisions is lower for Chinese MNEs as compared to Indian MNEs. As shown in Table 2, the coefficient of political risk is negative and significant for Indian OFDI in Model 4 ( $p<0.1$, while turns out to be positive and significant for Chinese OFDI in Model $2(p<0.1)$. Therefore, the number of Indian OFDIs is negatively associated with host country political risk, this not being the case for Chinese OFDI. Hence, Hypothesis 2 is also supported.

This result is in line with that of some prior comparative investigations, which reported a conventional negative impact of political risk on location of Indian OFDI, but a not significant impact for Chinese OFDI (De Beule and Duanmu, 2012; De Beule and Van Den Bulcke, 2012).

To sum up, we can state that the conventional wisdom derived from research on developed-country MNEs, which suggests a negative influence of political risk on location decisions, is valid for Indian MNEs but not for Chinese MNEs. As we argued above, differences in their respective home institutional environments may lead Chinese firms to be less risk averse. While the economic growth model in China has been mainly driven by the Chinese government, the private sector has played a leading role in India. One of the consequences of this is that SOEs prevail among Chinese MNEs, whereas most of Indian MNEs are private companies. Thus, Chinese MNEs are more influenced by political considerations, may behave not only as profit-maximizers when entering some risky countries, and may be more favored by good diplomatic relationships between the Chinese government and the government of those host countries.

In terms of the effects of control variables, as shown in Table 2, the coefficient of geographic distance is positive and significant for Chinese MNEs, but not significant for 
Indian MNEs. This suggests that geographic distance is a factor that not only does not deter Chinese firms, but even it has a positive effect on the number of their OFDIs. The motive of each OFDI decision may explain this result.

With regard to these motives, the coefficients of host market size and patent registrations are positive and significant in all models, although the statistical significance is higher for Chinese OFDI. This suggests that both market-seeking and strategic-asset seeking are a motivation for both Chinese and Indian MNEs even though stronger for Chinese MNEs. Moreover, the coefficient of natural resource endowment is positive and significant only in the subsample of Chinese OFDI. This leads us to conclude that resource-seeking is a significant OFDI driver only for Chinese MNEs.

Regarding the influence of administrative distance, our findings suggest that Indian OFDI is attracted by host countries belonging to the Commonwealth. However, Chinese OFDI seems not be attracted by host countries included in the Belt and Road initiative. Anyway, it is worth mentioning that this is a recent initiative by the Chinese government that is still in a relatively early stage of development. Finally, according to our results, diasporas seem to play a more important role in attracting Chinese OFDI as compared to Indian OFDI.

\section{Conclusion}

In this study we conducted a comparative analysis of the locational determinants of Chinese and Indian MNEs. We focused on the influence of two institutional factors that have been extensively analyzed in prior studies on OFDI location decisions: cultural distance and political risk. As reported above, our results indicate that the behavior of Chinese MNEs seems to be less conventional than that of their Indian counterparts. More precisely, whereas cultural distance and political risk discourage Indian OFDI, these factors do not seem to affect 
Chinese MNEs' location decisions. Thus, the behavior of Indian MNEs is closer to that observed in prior research on traditional MNEs originating in developed countries.

This article makes several contributions. With the increasing importance of emergingmarket MNEs, an epistemological debate has arisen among international business scholars on the applicability of existing theoretical underpinnings drawn from developed-country MNEs. Hence, from a theoretical standpoint, our study contributes to this debate by showing that there are differences among emerging-market MNEs arising mainly from the idiosyncratic characteristics of their respective home country institutional environments. Therefore, an analysis on the validity of existing theoretical frameworks for explaining the international behavior of emerging-market MNEs should consider these institutional differences before proposing general statements.

From an empirical viewpoint, this study also contributes to the increasing literature on Chinese and Indian MNEs by investigating differences among location factors for their OFDI decisions. Moreover, past research comparing locational determinants of Chinese and Indian OFDI did not focus on cultural issues. Therefore, to the best of our knowledge, this is one of the first comparative studies on Chinese and Indian OFDI that simultaneously addresses the influence of political risk and cultural distance as host country location factors.

Our study also has implications from a managerial perspective. As stated above, emerging-market MNEs from China and India are becoming key global players during the last years. As a consequence, they are increasing the intensity of competition in many industries, from energy and food to telecommunications and business process outsourcing. Managers of incumbent MNEs should know whether the strategic behavior of these newcomers differs or not from that observed in traditional developed-country MNEs. Thus, our study contributes to a better understanding of the factors that influence a key strategic decision of these emerging-market MNEs. Our findings suggest that Chinese MNEs behave in 
a less conventional way compared to their Indian counterparts when dealing with greater cultural distance and political risk in host countries.

Despite these contributions, there are several limitations to our study that provide opportunities for future research. First, since our empirical research is based on secondary data, some measures are limited, especially in the case of the institutional variables. This prevented us from including managerial perceptions on cultural distance and political risk. Future research may consider the institutional distance perceived by managers of Chinese and Indian MNEs when entering each host country.

Second, we used the common approach of compiling a cross-country index or indicator of political risk that is supposed to apply to all foreign companies. This applies to the concept of a macro political risk, namely, the environmental events which affect all foreign firms in a country. However, there is also a micro political risk, which is industry, firm, and even project-specific (Alon and Herbert, 2009; Kobrin, 1981). Building on this distinction, further research could investigate the potential impact of political risk upon specific types of emerging-market MNEs by using particular characteristics of the investing firm as the unit of analysis.

Finally, since our study is focused on emerging-market MNEs originating from two countries, the results may not be directly generalizable to MNEs from other emerging economies. Future studies should replicate our analysis with a dataset involving other emerging-market MNEs in order to deepen our understanding of whether they follow or not a conventional behavior when facing a high level of political risk and cultural distance in foreign countries. 


\section{References}

Alon, I., and Herbert, T.T. 2009. "A stranger in a strange land: Micro political risk and the multinational firm". Business Horizons 52(2): 127-137.

Anwar, A., and Mughal, M. 2012. "Economic freedom and Indian outward foreign direct investment: An empirical analysis”. Economics Bulletin 32(4): 2991-3007.

Anwar, A., and Mughal, M. 2013. "The role of diaspora in attracting Indian outward FDI". International Journal of Social Economics 40(11): 944-955.

Anwar, A.I., Hasse, R., and Rabbi, F. 2008. "Location determinants of Indian outward foreign direct investment: How multinationals choose their investment destinations?" Munich Personal RePEc Archive (MPRA) Paper No. 47397.

Bhardwaj, A., Dietz, J., and Beamish, P.W. 2007. "Host country cultural influences on foreign direct investment”. Management International Review 47(1): 29-50.

Blomkvist, K., and Drogendijk, R. 2013. "The impact of psychic distance on Chinese outward foreign direct investments". Management International Review 53(5): 659-686.

Brienen, M.J., Burger, M.J., and van Oort, F.G. 2010. “The geography of Chinese and Indian greenfield investments in Europe”. Eurasian Geography and Economics 51(2): 254273.

Brouthers, K. D. 2002. "Institutional, cultural and transaction cost influences on entry mode choice and performance”. Journal of International Business Studies 33(2): 203-221.

Buckley, P,J., Clegg, L.J., Cross, A.R., Liu, X., Voss, H., and Zheng, P. 2007. "The determinants of Chinese foreign direct investment". Journal of International Business Studies 38(4): 499-518.

Buckley, P.J., Forsans, N., and Munjal, S. 2012. "Host-home country linkages and host-home country specific advantages as determinants of foreign acquisitions by Indian firms". International Business Review 21(5): 878-890. 
Buckley, P,J., Munjal, S., Enderwick, P, and Forsans, N. 2016a. "Cross-border acquisitions by Indian multinationals: Asset exploitation or asset augmentation?" International Business Review 25(4): 986-996.

Buckley, P.J., Yu, P., Liu, Q., Munjal, S., and Tao, P. 2016b. “The institutional influence on the location strategies of multinational enterprises from emerging economies: Evidence from China's cross-border mergers and acquisitions". Management and Organization Review 12(3): 425-448.

Chin, H., and He, W. 2016. The Belt and Road Initiative: 65 countries and beyond. Hong Kong: Fung Business Intelligence Centre.

China International Trade Institute. 2015. Industrial cooperation between countries along the Belt and Road. China International Trade Institute.

Cuervo-Cazurra, A. 2012. "Extending theory by analyzing developing country multinational companies: Solving the Goldilocks debate”. Global Strategy Journal 2(3): 153-167.

Cuervo-Cazurra, A., and Genc, M. 2008. "Transforming disadvantages into advantages: Developing-country MNEs in the least developed countries". Journal of International Business Studies 39(6): 957-979.

Cui, L., and Jiang, F. 2010. "Behind ownership decision of Chinese outward FDI: Resources and institutions". Asia Pacific Journal of Management 27(4): 751-774.

Das, D.K. 2010. "China and India: Differentiating economic growth paradigms”. China Papers-New Zealand Contemporary China Research Centre-Victoria University of Wellington No. 27: 1-33.

De Beule, F. and Duanmu, D. 2012. "Locational determinants of internationalization: A firmlevel analysis of Chinese and Indian acquisitions". European Management Journal 30(3): 264-277. 
De Beule, F. and Van Den Bulcke, D. 2012. "Locational determinants of outward foreign direct Investment: an analysis of Chinese and Indian greenfield investments". Transnational Corporations 21(1): 1-34.

Deng, P. and Yang, M. 2015. "Cross-border mergers and acquisitions by emerging market firms: A comparative investigation”. International Business Review 24(1): 157-172.

Devonshire-Ellis, C. 2010. China-India comparison: An examination of 2011 direction and developments. New Delhi: Dezan Shira \& Associates.

Dow, D., and Karunaratna, A. 2006. "Developing a multidimensional instrument to measure psychic distance stimuli”. Journal of International Business Studies 37(5): 578-602.

Duanmu, J.L. 2012. "Firm heterogeneity and location choice of Chinese Multinational Enterprises (MNEs)". Journal of World Business 47(1): 64-72.

Duanmu, J.L. 2014. "State-owned MNCs and host country expropriation risk: The role of home state soft power and economic gunboat diplomacy". Journal of International Business Studies 45(8): 1044-1060.

Duanmu, J.L., and Guney, Y. 2009. “A panel data analysis of locational determinants of Chinese and Indian outward foreign direct investment”. Journal of Asia Business Studies 3(2): 1-15.

Ghemawat, P. 2001. "Distance still matters. The hard reality of global expansion". Harvard Business Review 79(8): 137-147.

Greene, W. 2003. Econometric analysis 5th edition. Upper Saddle River, NJ: Prentice Hall.

Han, J., Chu, X.Y., and Li, K. 2014. "China's ODI motivations, political risk, institutional distance and location choice". Theoretical Economics Letters 4: 540-547.

Hofstede, G., Hofstede, G.J., and Minkov, M. 2010. Cultures and organizations. Software of the mind. Intercultural cooperation and its importance for survival. 3rd edition. New York: McGraw-Hill. 
Hoskisson, R.E., Eden, L., Lau, C.M., and Wright, M. 2000. "Strategy in emerging economies". Academy of Management Journal 43(3), 249-267.

Huang, X., and Renyong, C. 2014. 'Chinese private firms' outward foreign direct investment: Does firm ownership and size matter?" Thunderbird International Business Review 56(5): 393-406.

Jain, N.K., Kothari, T., and Kumar, V. 2016. "Location choice research: Proposing new agenda". Management International Review 56(3): 303-324.

Jormanainen, I., and Koveshnikov, A. 2012. "International activities of emerging market firms: A critical assessment of research in top international management journals". Management International Review 52(5): 691-725.

Kang, Y., and Jiang, F. 2012. "FDI location choice of Chinese multinationals in East and Southeast Asia: Traditional economic factors and institutional perspective". Journal of World Business 47(1): 45-53.

Kim, J.U., and Aguilera, R.V. 2016. "Foreign location choice: Review and extensions". International Journal of Management Reviews 18(2): 133-159.

Kobrin, S.J. 1981. "Political assessment by international firms: Models or methodologies?" Journal of Policy Modeling 3(2): 251-270.

Kogut, B., and Singh, H. 1988. "The effect of national culture on the choice of entry mode". Journal of International Business Studies 19(3): 411-432.

Kolstad, I., and Wiig, A. 2012. "What determines Chinese outward FDI?" Journal of World Business 47(1): 26-34.

Kothari, T., Kotabe, M., and Murphy, P. 2013. "Rules of the game for emerging market multinational companies from China and India”. Journal of International Management 19(3): 276-299. 
Kutner, M., Nachtsheim, C., and Neter, J. 2004. Applied linear regression models. 4th edition. Irwin: McGraw-Hill.

Li, J., Li, Y., and Shapiro, D. 2012. "Knowledge seeking and outward FDI of emerging market firms: The moderating effect of inward FDI". Global Strategy Journal 2(4): $277-295$.

Long, J.S. 1997. Regression models for categorical and limited dependent variables. Thousand Oaks, CA: Sage.

Lu, J., Liu, X., Wright, M., and Filatotchev, I. 2014. "International experience and FDI location choices of Chinese firms: The moderating effects of home country government support and host country institutions". Journal of International Business Studies 45(4): 428-449.

Luo, Y., and Tung, R. L. 2007. "International expansion of emerging market enterprises: A springboard perspective”. Journal of International Business Studies 38(4): 481-498.

Luo, Y., and Wang, S. L. 2012. "Foreign direct investment strategies by developing country multinationals: A diagnostic model for home country effects". Global Strategy Journal 2(3): 244-261.

Luo, Y., Zhao, H., Wang, Y., and Xi, Y. 2011. "Venturing abroad by emerging market enterprises. A test of dual strategic intents". Management International Review 51(4): 433-459.

Malhotra, S., Zhu, P., and Locander, W. 2010. "Impact of host-country corruption on U.S. and Chinese cross-border acquisitions". Thunderbird International Business Review 52(6): 491-507.

Mathews, J.A. 2006. “Dragon multinationals: New players in 21st century globalization”. Asia Pacific Journal of Management 23(1): 5-27. 
Milelli, C., Hay, F., and Shi, Y. 2010. "Chinese and Indian firms in Europe: characteristics, impacts and policy implications". International Journal of Emerging Markets 5(3-4): $377-397$.

Nicholson, R. R., and Salaber, J. 2013. "The motives and performance of cross-border acquirers from emerging economies: Comparison between Chinese and Indian firms". International Business Review 22(6): 963-980.

Ning, L., and Sutherland, D. 2012. "Internationalization of China's private-sector MNEs: An analysis of the motivations for foreign affiliate formation". Thunderbird International Business Review 54(2): 169-182.

North, D.C. 1990. Institutions, institutional change and economic performance. Cambridge: Cambridge University Press.

Nunnenkamp, P., Sosa, M., Vadlamannati, K.C., and Waldkirch, A. 2012. "What drives India's outward FDI?’ Kiel Working Paper No. 1800.

Pak, Y.S., and Park, Y.R. 2004. "Global ownership strategy of Japanese multinational enterprises: A test of internalization theory”. Management International Review 44(1): $3-21$.

Peng, M.W., Wang, D.Y.L., and Jiang, Y. 2008. "An institution-based view of international business strategy: A focus on emerging economies". Journal of International Business Studies 39(5): 920-936.

Pradhan, J.P. 2008a. "Rise of Indian outward FDI: What implications does it hold for host developing countries?" Revista Economía: Teoría y Práctica No. 29: 9-49.

Pradhan, J.P. 2008b. "The evolution of Indian outward foreign direct investment: Changing trends and patterns". International Journal of Technology and Globalisation 4(1): 7086. 
Pradhan, J.P. 2011. "Emerging multinationals: A Comparison of Chinese and Indian outward foreign direct investment". International Journal of Institutions and Economies 3(1): 113-148.

Pradhan, J.P., and Singh, N. 2011. "Business group affiliation and location of Indian firms' foreign acquisitions". Journal of International Commerce, Economics and Policy 2(1): $19-41$.

Quer, D., Claver, E., and Rienda, L. 2012. "Political risk, cultural distance, and outward foreign direct investment: Empirical evidence from large Chinese firms". Asia Pacific Journal of Management 29(4): 1089-1104.

Ramasamy, B., Yeung, M., and Laforet, S. 2012. “China's outward foreign direct investment: Location choice and firm ownership". Journal of World Business 47(1): 17-25.

Rienda, L., Claver, E., and Quer, D. 2013. "The internationalisation of Indian multinationals: determinants of expansion through acquisitions". Journal of the Asia Pacific Economy 18(1): 115-132.

Rugman, A.M. 2010. "Book review: Globalization of Chinese enterprises”. The International Trade Journal 24(3): 352-354.

Rui, H., and Yip, G.S. 2008. "Foreign acquisitions by Chinese firms: A strategic intent perspective". Journal of World Business 43(2): 213-226.

Sun, S. L., Peng, M. W., Ren, B., and Yan, D. 2012. "A comparative ownership advantage framework for cross-border M\&As: The rise of Chinese and Indian MNEs". Journal of World Business 47(1): 4-16.

Tolentino, P. E. 2010. "Home country macroeconomic factors and outward FDI of China and India”. Journal of International Management 16(2): 102-120.

Van der Putten, F.P., Seaman, J., Huotari, M., Ekman, A., and Otero-Iglesias, M. 2016. Europe and China's New Silk Roads. European Think-tank Network on China (ETNC). 
Wright, M., Filatotchev, I., Hoskisson, R.E., and Peng, M.W. 2005. "Strategy research in emerging economies: Challenging the conventional wisdom". Journal of Management Studies 42(1): 1-33.

Xia, J., Ma, X., Lu, J.W., and Yiu, D. W. 2014. "Outward foreign direct investment by emerging market firms: A resource dependence logic". Strategic Management Journal 35(9): 1343-1363.

Xu, D., and Meyer, K.E. 2013. "Linking theory and context: 'Strategy research in emerging economies' after Wright et al. (2005)". Journal of Management Studies 50(7): 13221346.

Yang, Y., Yang, X., Chen, R., and Allen, J.P. 2014. "What drives emerging-economy outbound FDI decisions to obtain strategic assets?" Asian Business \& Management 13(5): 379-410.

Zhang, J., Jiang, J., and Zhou, C. 2014. "Diplomacy and investment - the case of China". International Journal of Emerging Markets 9(2): 216-235. 
Table 1 Descriptive statistics and correlations

\begin{tabular}{|c|c|c|c|c|c|c|c|c|c|c|c|c|}
\hline & Mean & $\begin{array}{l}\text { Standard } \\
\text { deviation }\end{array}$ & 1 & 2 & 3 & 4 & 5 & 6 & 7 & 8 & 9 & 10 \\
\hline 1. Host market size & 11.041 & 0.936 & & & & & & & & & & \\
\hline 2. Host market growth & 4.071 & 2.663 & -0.372 & & & & & & & & & \\
\hline $\begin{array}{l}\text { 3. Natural resource } \\
\text { endowment }\end{array}$ & 8.609 & 14.113 & -0.264 & 0.203 & & & & & & & & \\
\hline 4. Patent registrations & 3.300 & 1.117 & 0.856 & -0.238 & -0.104 & & & & & & & \\
\hline 5. Geographic distance & 3.833 & 0.267 & -0.089 & -0.103 & 0.180 & -0.096 & & & & & & \\
\hline $\begin{array}{l}\text { 6. Administrative } \\
\text { distance (China) }\end{array}$ & 0.340 & 0.474 & 0.021 & 0.339 & -0.173 & -0.016 & -0.595 & & & & & \\
\hline $\begin{array}{l}\text { 7. Administrative } \\
\text { distance (India) }\end{array}$ & 0.290 & 0.456 & -0.246 & 0.082 & 0.158 & -0.154 & 0.135 & -0.157 & & & & \\
\hline 8. Diaspora (China) & 0.160 & 0.368 & 0.127 & 0.167 & -0.057 & 0.193 & -0.296 & 0.324 & 0.071 & & & \\
\hline 9. Diaspora (India) & 0.190 & 0.392 & 0.018 & -0.045 & -0.085 & 0.036 & -0.123 & 0.148 & 0.457 & 0.155 & & \\
\hline 10. Cultural distance & 1.958 & 1.039 & 0.024 & -0.296 & -0.025 & 0.026 & 0.586 & -0.436 & -0.076 & -0.285 & -0.131 & \\
\hline 11. Political risk & 62.812 & 12.699 & -0.434 & 0.446 & 0.000 & -0.279 & -0.066 & 0.218 & -0.030 & -0.088 & -0.209 & -0.282 \\
\hline
\end{tabular}

Correlations above $/ 0.167 /$ are significant at 0.05 level.

Correlations above / $0.238 /$ are significant at 0.01 level. 
Table 2 Results of negative binomial regression analysis

\begin{tabular}{|c|c|c|c|c|}
\hline & $\begin{array}{l}\text { Model } 1 \\
\text { (China) }\end{array}$ & $\begin{array}{l}\text { Model } 2 \\
\text { (China) }\end{array}$ & $\begin{array}{l}\text { Model } 3 \\
\text { (India) }\end{array}$ & $\begin{array}{l}\text { Model } 4 \\
\text { (India) }\end{array}$ \\
\hline \multicolumn{5}{|c|}{ Control variables } \\
\hline \multirow{2}{*}{ Host market siz } & $0.340^{*}$ & $0.376^{*}$ & $0.462 \dagger$ & $0.395 \dagger$ \\
\hline & $(0.166)$ & $(0.162)$ & $(0.260)$ & $(0.207)$ \\
\hline \multirow{2}{*}{ Host market } & 0.045 & 0.016 & 0.046 & 0.036 \\
\hline & $(0.051)$ & $(0.455)$ & $(0.046)$ & $(0.038)$ \\
\hline \multirow{2}{*}{ Natural resou } & $0.011 \dagger$ & $0.013^{*}$ & 0.013 & 0.008 \\
\hline & $(0.006)$ & $(0.006)$ & $(0.010)$ & (0.009) \\
\hline \multirow[b]{2}{*}{ Patent registr } & $0.589 * * *$ & $0.613 * * *$ & $0.347 \dagger$ & $0.349 *$ \\
\hline & $(0.165)$ & $(0.155)$ & $(0.192)$ & $(0.146)$ \\
\hline \multirow[b]{2}{*}{ Geographic d } & $0.927 * *$ & $0.940^{*}$ & -0.013 & 0.634 \\
\hline & $(0.322)$ & $(0.390)$ & $(0.439)$ & $(0.434)$ \\
\hline \multirow{2}{*}{ Administrativ } & -0.081 & -0.238 & $0.844 * * *$ & $0.752 * * *$ \\
\hline & $(0.265)$ & $(0.283)$ & $(0.191)$ & $(0.203)$ \\
\hline \multirow{2}{*}{ Diaspora } & $0.790 * * *$ & $0.879 * * *$ & -0.106 & -0.111 \\
\hline & $(0.186)$ & $(0.209)$ & $(0.216)$ & $(0.219)$ \\
\hline \multicolumn{5}{|c|}{ Independent variables } \\
\hline \multirow{2}{*}{ Cultural distan } & & -0.080 & & $-0.480 * * *$ \\
\hline & & $(0.086)$ & & $(0.121)$ \\
\hline \multirow{2}{*}{ Political risk } & & $0.013 \dagger$ & & $-0.015 \dagger$ \\
\hline & & (0.008) & & (0.009) \\
\hline Log likelihood & -175.632 & -175.115 & -115.585 & -114.325 \\
\hline LR Chi-square & $58.507 * * *$ & $59.541 * * *$ & $19.662 * *$ & $22.182 * *$ \\
\hline
\end{tabular}

Dependent variable: Number of OFDIs

Standard errors in parentheses

$\dagger \mathrm{p}<0.10 ; * \mathrm{p}<0.05 ; * * \mathrm{p}<0.01 ; * * * \mathrm{p}<0.001$

\footnotetext{
${ }^{1}$ We also performed the regressions limiting the dataset to those host countries receiving more investments, namely, at least three investments. The results using this threshold level of investments were similar than those reported for the full dataset.
} 